\title{
Bacterial Contamination of Vegetables Irrigated with Wastewater
}

\author{
Mamdouh S. Al-Gamal ${ }^{1}$, A.A.K. Abou-Arab ${ }^{2}$, M.A. Abou Donia ${ }^{2}$, Lamyaa El-Sideek ${ }^{2}$, Ahmed \\ A. Radwan ${ }^{1}$ and Mohamed Eid T. ${ }^{2}$ \\ ${ }^{1}$ Botany and Microbiology Dept., Faculty of Science (Boys), Al-Azhar University, Cairo, Egypt. \\ ${ }^{2}$ Food Toxicology and Contaminants Dept., National Research Centre, 33 El Buhouth St. (former \\ ElTahrir St. ) Dokki, Giza, Egypt. Postal Code: 12622.
}

Received: 24 Oct. 2019 / Accepted 27 Nov. 2019 / Publication date: 15 Dec. 2019

\begin{abstract}
Population densities and freshwater resources are not equally distributed around the world. This has forced farmers to use wastewater for the irrigation of food crops Although wastewater is an important source of essential nutrients for plants, many environmental, sanitary, and health risks are also associated with the use of wastewater for crop irrigation due to the presence of microbes and pathogenic bacterial strains that have health risk importance which may transfer to the plant crops when this water used for irrigation and affect human health especially when this crops eaten raw (fresh vegetables). Like many other countries, wastewater is frequently used for crops irrigation without any prior treatment in peri-urban areas of Egypt. Present study demonstrates contamination level of irrigation water canals that branched from river Nile and receives wastewater from nearby drains or urban human activities or village around the water canals that dump their waste in the irrigation canals and effect of such wastewater on contamination of soil and fresh vegetables like lettuce, arugula and cucumber that growing in some areas (Qalubia, Giza and Sharkia) that irrigated by such water. Microbial load within the vegetable samples ranged from $5.2 \mathrm{log} \mathrm{cfu} / \mathrm{gm}$ to $7.9 \mathrm{log}$ $\mathrm{cfu} / \mathrm{gm}$, from $4.7 \mathrm{log} \mathrm{cfu} / \mathrm{gm}$ to $6.3 \mathrm{log} \mathrm{cfu} / \mathrm{gm}$ for total coliforms and from $4.0 \mathrm{log} \mathrm{cfu} / \mathrm{gm}$ to $5.6 \mathrm{log}$ $\mathrm{cfu} / \mathrm{gm}$ for staphylococci counts. The observed mean counts in both irrigation water and the fresh vegetable samples were higher than the recommended standards of $1.0 \times 10^{2} \mathrm{cfu} / \mathrm{ml}$ (or $\mathrm{cfu} / \mathrm{gm}$ ) for THB and $1.0 \times 10^{1} \mathrm{cfu} / \mathrm{ml}$ (or $\left.\mathrm{cfu} / \mathrm{gm}\right)$ for total coliform. There was a positive correlation between water contamination and vegetable contamination during study period. Also many pathogenic bacterial species have been isolated from examined samples (wastewater, soil and raw vegetables) as E.coli sp., Salmonella sp., proteus sp., klebseilla, citrobacter sp., S. aureus, pseudomonas sp. and providencia $s p$. The results obtained from this study gives information not only on the microbial load but also on their origins (wastewater) and stimulate concerned entities in Egypt for the necessarily treatment of wastewater before use.
\end{abstract}

Keywords: Wastewater, Irrigation water, Fresh vegetables, Pathogenic bacteria, total coliforms.

\section{Introduction}

Fresh vegetables are strongly recommended for the human diet because of their contents of plant proteins, vitamins, and fibers that support human heath, additionally they give the body the necessary minerals, fats, oils and vitamins in the right proportion that support human growth and cell development (Ehimemen et al., 2019).WHO/FAO reports to recommend 400g of fruit and vegetables at least every day to prevent chronic diseases such as heart disease, cancer, diabetes and obesity, and Compensates for several micronutrient deficiencies, especially in less developed countries (WHO and FAO 2003). In contrast to their health benefits, the consumption of fresh vegetables has also been associated with risk of consumers (Beuchat et al., 2002; Weldezgina et al., 2016).

Bacteria are among the common vegetable contaminants Alemul et al., (2018). Foodborne illness due to of polluted fresh vegetables is a common phenomenon and has harm effects on human health as well as social and economic effects. Once pathogenic bacteria have been in contact with the growing environment, they can colonize and persist on fresh produce using a number of mechanisms Alegbeleye et al., (2018). Many studies on bacterial quality of vegetables was done for example E.coli, staph, enterococcus, klebsiella and citrobacter have been isolated from vegetables (potato,

Corresponding Author: Mohamed Eid, Food Toxicology and Contaminants Dept., National Research Centre, 33 El Buhouth St. (former ElTahrir St.,) Dokki, Giza, Egypt. Postal Code: 12622.

E-mail: muhamed.eid.nrc@gmail.com 
tomato, Cucumber, pepper, onion and carrot) in northern Nigeria Ehimemen et al., (2019). However, Gambo et al., (2019) isolate many bacterial pathogens from vegetable samples. On the other hands, Obeng et al., (2018) found that of the 120 tomatoes samples purchased from markets, eleven different bacteria were isolated. They were Bacillus sp., Enterobacter sp., Citrobacter sp., Klebsiella sp., Shigella sp., Proteus mirabilis, Klebsiella oxytoca, Enterobacter cloacae, Citrobacter koseri, and Klebsiella pneumoniae. While Kouassi et al., (2019) detect a huge number of bacterial count and total coliforms in Lettuce samples, in addition to isolate many pathogenic bacterial strains including Escherichia coli, Salmonella sp. and Staphylococcus aureus coagulase positive from it. Most of the pathogenic strains isolate are of human health risks effect, where Salmonella sp. is the most common cause of bacterial foodborne illness, they cause infection of the gastrointestinal tract resulting in diarrhea humans infected by Salmonella typically develop nausea, vomiting, fever, abdominal cramps and diarrhoea.

Surveys were performed in several countries to determine local prevalence of pathogenic microorganisms on vegetables (Rai et al., 2007; Afolabi et al 2010; Badawy et al., 2013; Debanthan et al., 2014; Awe S. Gimba et al., 2015; Markhous et al. 2019).

The sources of vegetables contamination occur mostly before harvesting, either by contaminated manure, sewage, irrigation water, and wastewater from livestock operations or directly from wild and domestic animals or during harvesting, transport, processing, distribution, and marketing or even at home (Eraky et al., 2014 ; Maffei et al. 2016). The use of wastewater for irrigation affects the quality of raw vegetables and human health. It could be the possible source of pathogenic microorganisms on vegetables (Mritunjay et al., 2018). One major cause of vegetable contamination could be the unavailability of hygienic irrigation water. Pathogens can be transmitted to vegetables and cause outbreaks of illnesses when these are consumed. Islam et al., (2004) stated that a wide range of pathogens can be transferred to plants via irrigation water, surviving several days both on external and internal parts of the plant. In many cases pathogens have the ability to enter into the plant tissues through wound surfaces and stomatal cavities (Gomes et al., 2009 and Aruscavage et al., 2008). Studies examining pathogen contamination of vegetables also observations of increased presence of disease in areas applied wastewater irrigation for crops with little or no wastewater treatment indicated that contaminated irrigation water might indeed be a source of foodborne pathogens on fresh produce (Steele and Odumeru, 2004; Obeng et al., 2018 ; Mritunjay et al., 2018 and Ehimemen et al., 2019)

Contamination of irrigation water can serve as a main source of vegetables contamination. On the other hand, heavy population problem and freshwater resources are not equally distributed around the world. This has forced farmers to use wastewater for the irrigation of food crops Khalid et al., (2018). Although wastewater is an important source of essential nutrients for plants, many environmental, sanitary, and health risks are also associated with the use of wastewater for crop irrigation due to the presence of toxic contaminants and microbes Khalid et al., (2018). Surveys were performed in several countries to determine bacterial load and prevalence of pathogenic microorganisms in wastewater. Cui et al., (2019) found that total heterotrophic bacteria ranged from $\left(3.6 \times 10^{6}\right.$ to $\left.4.3 \times 10^{6} \mathrm{cfu} / \mathrm{ml}\right)$ for raw wastewater and total coliform ranged from $\left(1.0 \times 10^{4}\right.$ to $6.0 \times 10^{5}$ $\mathrm{cfu} / \mathrm{ml})$, while the main fecal coliforms count was $\left(2.4 \times 10^{4} \mathrm{cfu} / \mathrm{ml}\right)$, the result were higher than recommended standards for wastewater used for agriculture irrigation. In another study on water samples collected from some irrigation canal at Nile delta /Egypt, the colony forming unit of the total bacterial counts ranged from $\left(158 \times 10^{5}\right.$ to $\left.0.1 \times 10^{5} \mathrm{cfu} / \mathrm{ml}\right)$ and the count of lactose-utilizing Gramnegative bacteria, ranged from count $\left(93 \times 10^{3}\right.$ to $\left.0.1 \times 10^{3} \mathrm{cfu} / \mathrm{ml}\right)$, also many bacterial strains was isolated and identified as Pseudomonas aeruginosa, Pseudomonas otitis, Enterobacter cloacae, Enterobacter cancerogenus and Proteus mirabilis. The high bacterial and coliform count indicate that these canal subjected to fecal and sewage contamination, the increasing in the count of bacteria was due to the effect of industrial, domestic and agricultural wastes discharge into the water from the surrounding area Hassan et al., (2018).

Farhadkhani et al., (2018) found that secondary treatment of wastewater is a common environmental management strategy used worldwide, especially in developing countries. However, the microbial quality of such wastewater is a public health concern for irrigation of crops eaten raw. The results of this study showed that the microbial quality of treated wastewater used to irrigate crops does not meet WHO guidelines for irrigation of root and leafy crops (WHO, 2006). So, the main 
drivers of wastewater use in irrigated agriculture are a combination of the following aspects: limited capacities of cities to treat their wastewater, causing pollution of soils, water bodies and traditional irrigation water sources; lack of alternative (cheaper, similarly reliable, available or safer) water sources in the physical environment; urban food demand and market incentives favoring food production in the proximity of cities, where water sources are usually polluted (Platform, 2010). Globally, the use of untreated wastewater for urban and peri-urban agriculture accounts for about $11 \%$ of all the irrigated croplands (Thebo et al., 2017). It is estimated that $10 \%$ of the global population consumes food produced from wastewater irrigation (WHO, 2006). The practice of crop irrigation with wastewater is not well-regulated in low-income countries, and the environmental and economic issues are poorly understood (Scott et al., 2010; Qadir et al., 2010). Some poor countries use raw sewage for irrigation purpose, although its use is considered illegal (Huibers et al., 2005). In less developed and low-income countries such as Asia, Latin America, and Africa, wastewater is used for irrigation without any treatment (Mcheik, 2018; Sahotap et al., 2018; Ehimemen et al., 2019).

Egypt share of Nile water $55.5 \mathrm{BCM} / \mathrm{Y}$ does not meet with Egypt's water demands. The current available water resources in Egypt are limited and there is a major hole between the complete water supply and the flow water requests due to urbanization and population growth. The current population in Egypt is 94 million capita (CAPMAS 2017). To satisfy the Egyptian water demands, the shortage of $13.5 \mathrm{BCM} / \mathrm{Y}$ of water should be Achived through non-confidential and alternative water resources such as indirect wastewater reuse and agriculture wastewater reuse of good quality Tamer et al., (2017).

Since urbanization leads to an increase in wastewater production, wastewater has become a potential and cheap source of water for agricultural activities Huibers et al., (2005). Because the use of potable water for irrigation is very expensive El-Gamal et al., (2016). The second option still the use of surface water from contaminated rivers and streams (Obi., 2002; Kayombo et al 2018), which poses potential human health risks due to the presence of pathogenic organisms from infected livestock or human hosts Kayombo et al., (2015). As a result, there is a sever risk for the health of consumers of crops irrigated with contaminated water, especially fresh vegetables, which may at times be consumed without cooking when eaten as salad (raw) Abaza et al., (2018). Several studies have shown that raw vegetables may harbor potential food-borne pathogens (Beuchat et al., 2002 ; Kayombo et al., 2018; Sahotap et al., 2018; Akinde et al 2016 ; James.Y Gambo et al., 2019).

Most of Egypt population lives in the valley and the delta of the Nile, which comprise about $3.5 \%$ of Egypt (Approximately 35,000 $\mathrm{km}^{2}$ ). More than 4,600 villages and Tens of hundreds of smaller entities (called E zba(s)) are spread alongside this area. Most of cities of Egypt are found in this area as well. The area looks like one cultivated land area served by thousands of nested irrigation canals from different levels. More than $50,000 \mathrm{~km}(\mathrm{~s})$ of irrigation and drainage canals cover this area in a very dense system. The sewage services were not provided to most of the rural areas (villages and entities), and therefore the sewage in this rural area is collected and dumped into drainage and irrigation systems. So, farmers have no other feasible solutions unless other interventions are developed and disseminated among them El-Gamal et al., (2016). So, this study will cover and give information about using this irrigation canals in agriculture and the human health effect of using this water for irrigation of vegetables that used raw.

\section{Materials and Methods}

\section{Materials}

\section{Samples:}

1. A total of 135 samples of irrigation water (27), soil (27) and vegetables 81 (27 samples of each Arugula, Lettuce and Cucumber) were collected from three Egyptian Governorates, i.e. Giza, Sharkia and Qalubia. Water samples were collected from wastewater irrigation canal that used to irrigate vegetables and the corresponding soil to assess the bacterial quality of wastewater irrigation canal and the corresponding soil and vegetables.

2. The samples of wastewater $(200 \mathrm{ml})$ were collected in sterile bottle, soil sample collected from depth $20 \mathrm{~cm}$ in sterile bags and vegetable samples were collected in sterile bags. All samples 
transported promptly to the laboratory in ice boxes for microbiological analysis within few hours of collection.

Medium:

Buffered peptone solution, Plate count agar plates, Violet red bile agar plates, Paired parker agar media, Mackonkey agar, Nutrient agar, S.S agar plates, and EMB agar media were obtained from Oxoid, England for microbiological analysis of water, soil, and vegetables collected samples.

\section{Methods}

\section{Microbiological analysis}

Total count bacteria: Water samples collection $(25 \mathrm{ml})$, soil samples $(25 \mathrm{~g})$ and vegetable samples $(25 \mathrm{~g})$ were weighed and blended in sterile $225 \mathrm{ml}$ buffered peptone solution under sterile condition. Aliquots $(1.0 \mathrm{ml})$ of each homogenate were serially diluted in serial dilution $\left(10^{-1}\right.$ to $\left.10^{-9}\right)$. Sterile plate count agar plates were aseptically inoculated triplicate with aliquot of serial dilutions of the wastewater, soil and vegetable samples and incubated at $37^{\circ} \mathrm{C}$ for 24 hours to calculate total bacterial count where colonies appear counted and calculated Hassan et al., (2018).

Total coliform bacteria: To assess the total coliforms $1.0 \mathrm{ml}$ aliquot of serial dilutions of the wastewater, soil and vegetable samples were aseptically inoculated triplicate into violet red bile agar plates and incubated at $37^{\circ} \mathrm{C}$ for 24 hours. Red colonies calculated and counted (APHA, 1998 and FDA, 2002).

Total Staphylococci: The counts of Staphylococci were assessed using paired parker agar media, 0.1 $\mathrm{ml}$ of serially diluted aliquot streaked on the surface of the agar plates and incubated for 48 hours, black colonies calculated and counted (FDA, 2002).

Isolation and detection of pathogenic bacteria: To detect pathogenic bacteria, $1 \mathrm{ml}$ of aliquot streaked on various media type (Mackonkey, Nutrient agar, S.S agar plates and EMB agar media) and incubated at $37^{\circ} \mathrm{C}$ for 24 hours, a typical discrete colonies were sub cultured and purified on nutrient agar plates for the development of highly Purified isolates, which were stored on nutrient agar slants for subsequent characterization and identification tests at $4^{\circ} \mathrm{C}$. Akinde et al., (2016). Identification of all bacterial isolates was by microscopic, morphologic, and biochemical characterization. The biochemical tests were interpreted to determine the presumptive nomenclature of the potential pathogenic bacteria isolates (mostly enteric) through Bergey's Manual of Determinative Bacteriology Akinde et al., (2016).

\section{Statistical analysis:}

The different parameters analyzed were then subjected to an analysis of variance (ANOVA) with the Excel software. For this purpose, a Two-factor with and without replication ANOVA were used to test the variability between the samples of different and same type Statistical differences with Pvalues under 0.05 were considered significant. Also, correlation test using Microsoft Excel Data analysis was used to found positive and Negative correlation between parameters in all samples (Elbeih and El-Zeiny, 2018).

\section{Results and Discussion}

Determination of total bacterial count, total coliforms and staphylococci count in irrigation water, soil and vegetable samples.

Untreated wastewater contains a large range of pathogenic microorganisms, where the type of pathogens varies from region and time. Total count bacteria (TCB), total coliform bacteria, and staphylococci bacteria were determined in the collected samples of wastewater, soil and vegetables irrigated by wastewater, which collected from Qalubia, Sharkia and Giza Governorates and the collection data were presented in Table (1). The mean $\log$ count $(\mathrm{cfu} / \mathrm{ml})$ of TCB in wastewater samples was 7.9, 7.7 and 6.9 in Qalubia, Sharkia and Giza, respectively. The corresponding values of 
total coliform bacteria were 7.0, 6.4 and 5.7 as well as $6.1,6.2$ and 5.0 with staphylococci. With respect to soil samples, data in Table (2) indicated that mean log count (cfu/ml) of TCB, total coliform bacteria, and staphylococci bacteria in the samples collection from Qalubia were 7.7, 6.8 and 6.3, respectively. While in the samples collection from Sharkia, mean log count ( $\mathrm{cfu} / \mathrm{ml})$ was $7.2,6.3$ and 5.9, respectively. The corresponding data in Giza samples was 6.3, 5.5 and 5.0.

Table 1: Log count (cfu/ml) of total bacteria, total coliforms and Staphylococci of wastewater irrigation canal in Qalubia, Sharkia and Giza Governrates

\begin{tabular}{|c|c|c|c|c|c|c|}
\hline \multirow{3}{*}{ Bacteria } & \multicolumn{6}{|c|}{ Log count of bacteria (cfu/ml) } \\
\hline & \multicolumn{2}{|c|}{ Qalubia $(\mathrm{n}=9) *$} & \multicolumn{2}{|c|}{ Sharkia $(n=9)$} & \multicolumn{2}{|c|}{$\operatorname{Giza}(n=9)$} \\
\hline & $\begin{array}{c}\operatorname{Mean} \pm \\
\text { SD }\end{array}$ & Range & $\operatorname{Mean} \pm \mathrm{SD}$ & Range & Mean \pm SD & Range \\
\hline Total count & $7.9 \pm 0.50$ & $6.6-8.40$ & $7.7 \pm 0.32$ & $7.2-8.10$ & $6.9 \pm 0.44$ & $6.2-7.50$ \\
\hline Total Coliforms & $7.0 \pm 0.40$ & $6.4-7.60$ & $6.4 \pm 0.57$ & $5.3-7.00$ & $5.7 \pm 0.33$ & $5.2-6.20$ \\
\hline Staphylococci & $6.1 \pm 0.60$ & $5.4-7.10$ & $6.2 \pm 0.64$ & $5.3-6.90$ & $5.0 \pm 0.50$ & $4.3-5.70$ \\
\hline
\end{tabular}

*Number of samples

WHO guidelines, $10^{3} \mathrm{cfu} / \mathrm{ml}$ for total count and Staphylococci

WHO guidelines, $10^{2} \mathrm{cfu} / \mathrm{ml}$ for total coliform

Table 2. Log count (cfu/ml) of total bacteria, total coliforms and Staphylococci of soil in Qalubia, Sharkia and Giza Governrates

\begin{tabular}{lcccccc}
\hline \multirow{1}{*}{ Bacteria } & \multicolumn{2}{c}{ Qalubia $(\mathbf{n}=\mathbf{9}) *$} & \multicolumn{2}{c}{ Log count of bacteria $(\mathbf{c f u} / \mathbf{m l})$} & \multicolumn{2}{c}{ Sharkia $(\mathbf{n}=9)$} \\
& Mean \pm SD & Range & Mean \pm SD & Range & Mean \pm SD & Range \\
\hline Total count & $7.7 \pm 0.60$ & $6.9-8.70$ & $7.2 \pm 0.77$ & $6.1-8.00$ & $6.3 \pm 0.35$ & $5.9-6.90$ \\
Total Coliforms & $6.8 \pm 0.30$ & $6.2-7.20$ & $6.3 \pm 0.67$ & $5.2-6.90$ & $5.5 \pm 0.74$ & $4.3-6.60$ \\
Staphylococci & $6.3 \pm 0.55$ & $5.0-6.70$ & $5.9 \pm 0.68$ & $5.1-6.80$ & $5.0 \pm 0.44$ & $4.3-5.50$ \\
\hline
\end{tabular}

*Number of samples

WHO guidelines, $10^{3} \mathrm{cfu} / \mathrm{ml}$ for total count and Staphylococci

WHO guidelines, $10^{2} \mathrm{cfu} / \mathrm{ml}$ for total coliform

On the other hand, total count bacteria (TCB), total coliform bacteria, and staphylococci bacteria were recorded in the vegetable samples (Table 3). Data indicated that mean total count bacteria of Cucumber were 5.7, 6.6 and $6.3(\log \mathrm{cfu} / \mathrm{ml})$ in the samples collection from Giza, Qalubia and Sharkia, respectively. The corresponding values of Lettuce were 6.2, 7.0 and 6.4 as well as in Arugula were 6.3, 6.9 and $6.7(\log \mathrm{cfu} / \mathrm{ml})$. Regarding to total coliform count, mean $(\log \mathrm{cfu} / \mathrm{ml})$ of Cucumber were 4.9, 5.0 and 5.2 in the samples collection from Giza, Qalubia and Sharkia, respectively. The corresponding values of Lettuce were 5.1, 5.7\& 5.5 and 5.2, 5.6 \& 5.6 in Lettuce and Arugula samples, respectively. In the samples of Giza, Qalubia and Sharkia, data revealed that staphylococci $(\log \mathrm{cfu} / \mathrm{ml})$ were $(4.6,4.5 \& 4.5)$ in Cucumber samples, $(4.6,5.2 \& 4.7)$ in Lettuce samples and $(5.0,5.0 \& 4.9)$ in Arugula samples.

The result of this study does not meet with WHO guidelines for irrigation of root and leafy crops $\left(10^{3} \mathrm{cfu} / \mathrm{ml}\right.$ or $\left.\mathrm{cfu} / \mathrm{gm}\right)$ (WHO, 2006 and Akinde et al 2016). The high total bacterial count and coliforms count in the wastewater canals and vegetables irrigated by wastewater indicate that this canal subjected to fecal contamination and such contamination transferred to irrigated vegetables and this is might be due to that most of villages and thousands of smaller entities (called ezba), which scattered around the study area were not provided with sewage services, and therefore the sewage in this rural area is collected and dumped in drainage and irrigation systems water or due to mixing of drainage water with surface water of canals.

Data analysis showed significant differences $(\mathrm{P} \leq 0.05)$ in $(\mathrm{TCB})$ and coliforms count as well as staphylococci counts of wastewater and soil among the three governorates (Giza, Sharkia and Qalubia), this is might be due to the source of contamination where some irrigation canals have small size and bottom so the wastewater discharge within them, which make highly contaminated and concentrated, while others which have large surface area and more depth dilution of wastewater is done. Also, significant differences $(\mathrm{P} \leq 0.05)$ are noticed in $\mathrm{TCB}$, total coliforms and staphylococci counts of vegetables among the same three governorates as well as between the vegetables type in the 
same governorate. This difference might be due the amount of water each crop hold which are an important factor of exposure to pathogens Abaidoo et al., (2010), where leafy vegetables (Arugula and Lettuce) have increased surface area than fruity vegetables (Cucumber), so they can hold more amount of contaminated water and so are subjected to contamination than other. The present investigation indicated that TCB and total coliforms in the three governorates are of order Qalubia $>$ Sharkia $>$ Giza. These results proved that, there is appositive correlation between total coliforms and TCB in wastewater canal and soil, which recorded $(r=0.86,0.95$ and 0.88$)$ and $(r=0.88,0.95$ and 0.92) for TCB and total coliforms, respectively. Also, a positive correlation between TCB in wastewater and vegetables were observed, which where $(\mathrm{r}=0.85,0.94$ and 0.93$)$ for Cucumber, $(\mathrm{r}=$ 0.93, 0.97 and 0.94) for Lettuce and $(r=0.91,0.93$ and 0.96) for Arugula. On the other hand, a positive correlation between coliform bacteria vegetables was ( $\mathrm{r}=0.88,0.92$ and 0.91$)$ for Cucumber, $(r=0.94,0.98$ and 0.95$)$ for Lettuce and $(r=0.90,0.98$ and 0.95$)$ for Arugula in Giza, Qalubia and Sharkia, respectively.

Table 3: Log count (cfu/gm) of total bacteria, total coliform and Staphylococci of vegetables samples irrigated with wastewater canal in Qalubia, Sharkia and Giza Governorates.

\begin{tabular}{|c|c|c|c|c|c|c|c|c|c|c|}
\hline \multirow{2}{*}{$\frac{\vartheta}{\bar{E}}$} & \multirow{2}{*}{$\begin{array}{c}\text { Paramete } \\
\mathbf{r} \\
\text { Governorates }\end{array}$} & \multicolumn{3}{|c|}{$\begin{array}{l}\text { Log count (cfu/gm) } \\
\text { of total bacteria }\end{array}$} & \multicolumn{3}{|c|}{$\begin{array}{c}\text { Log count }(\mathbf{c f u} / \mathrm{gm}) \\
\text { of total Coliforms }\end{array}$} & \multicolumn{3}{|c|}{$\begin{array}{l}\text { Log count (cfu/gm) } \\
\text { of Staphylococci }\end{array}$} \\
\hline & & Giza & Qalubia & Sharkia & Giza & Qalubia & Sharkia & Giza & Qalubia & Sharkia \\
\hline \multirow{2}{*}{ 离 } & Range & $\begin{array}{c}5.2- \\
6.4\end{array}$ & $\begin{array}{c}5.8- \\
7.1\end{array}$ & $\begin{array}{c}5.6- \\
6.9\end{array}$ & $\begin{array}{c}4.3- \\
5.3\end{array}$ & $\begin{array}{c}4.7- \\
5.7\end{array}$ & $\begin{array}{c}4.8- \\
5.7\end{array}$ & $\begin{array}{c}4.0- \\
5.1\end{array}$ & $\begin{array}{c}4.2- \\
4.9\end{array}$ & $\begin{array}{c}4.3- \\
4.8\end{array}$ \\
\hline & $\begin{array}{l}\text { Mean } \pm \\
\text { SD }\end{array}$ & $\begin{array}{l}5.7 \pm \\
0.39\end{array}$ & $\begin{array}{l}6.6 \pm \\
0.33\end{array}$ & $\begin{array}{l}6.3 \pm \\
0.39\end{array}$ & $\begin{array}{l}4.9 \pm \\
0.29\end{array}$ & $\begin{array}{l}5.0 \pm \\
0.29\end{array}$ & $\begin{array}{l}5.2 \pm \\
0.28\end{array}$ & $\begin{array}{l}4.6 \pm \\
0.40\end{array}$ & $\begin{array}{l}4.5 \pm \\
0.20\end{array}$ & $\begin{array}{l}4.5 \pm \\
0.15\end{array}$ \\
\hline \multirow{2}{*}{ 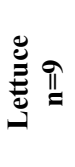 } & Range & $\begin{array}{l}5.5- \\
7.2\end{array}$ & $\begin{array}{l}6.1- \\
7.8\end{array}$ & $\begin{array}{c}5.9- \\
7.0\end{array}$ & $\begin{array}{c}4.7- \\
5.3\end{array}$ & $\begin{array}{c}5.2- \\
6.3\end{array}$ & $\begin{array}{c}5.0- \\
5.8\end{array}$ & $\begin{array}{l}4.2- \\
5.3\end{array}$ & $\begin{array}{c}4.5- \\
5.5\end{array}$ & $\begin{array}{c}4.5- \\
5.4\end{array}$ \\
\hline & $\begin{array}{l}\text { Mean } \pm \\
\text { SD }\end{array}$ & $\begin{array}{l}6.2 \pm \\
0.36\end{array}$ & $\begin{array}{l}7.0 \pm \\
0.41\end{array}$ & $\begin{array}{l}6.4 \pm \\
0.35\end{array}$ & $\begin{array}{l}5.1 \pm \\
0.09\end{array}$ & $\begin{array}{l}5.7 \pm \\
0.41\end{array}$ & $\begin{array}{l}5.5 \pm \\
0.27\end{array}$ & $\begin{array}{l}4.6 \pm \\
0.32\end{array}$ & $\begin{array}{l}5.2 \pm \\
0.33\end{array}$ & $\begin{array}{l}4.7 \pm \\
0.32\end{array}$ \\
\hline \multirow{2}{*}{ 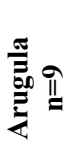 } & Range & $\begin{array}{l}5.6- \\
6.9\end{array}$ & $\begin{array}{l}5.8- \\
7.9\end{array}$ & $\begin{array}{l}6.0- \\
7.8\end{array}$ & $\begin{array}{c}5.0- \\
5.5\end{array}$ & $\begin{array}{c}5.3- \\
6.0\end{array}$ & $\begin{array}{c}5.2- \\
6.0\end{array}$ & $\begin{array}{c}4.7- \\
5.6\end{array}$ & $\begin{array}{c}4.5- \\
5.4\end{array}$ & $\begin{array}{c}4.6- \\
5.3\end{array}$ \\
\hline & $\begin{array}{l}\text { Mean } \pm \\
\text { SD }\end{array}$ & $\begin{array}{l}6.3 \pm \\
0.33\end{array}$ & $\begin{array}{l}6.9 \pm \\
0.51\end{array}$ & $\begin{array}{l}6.7 \pm \\
0.56\end{array}$ & $\begin{array}{l}5.2 \pm \\
0.16\end{array}$ & $\begin{array}{l}5.6 \pm \\
0.24\end{array}$ & $\begin{array}{l}5.6 \pm \\
0.28\end{array}$ & $\begin{array}{l}5.0 \pm \\
0.32\end{array}$ & $\begin{array}{l}5.0 \pm \\
0.31\end{array}$ & $\begin{array}{l}4.9 \pm \\
0.23\end{array}$ \\
\hline
\end{tabular}

*Number of samples

WHO guidelines, $10^{3} \mathrm{cfu} / \mathrm{ml}$ for total count and Staphylococci

WHO guidelines, $10^{2} \mathrm{cfu} / \mathrm{ml}$ for total coliform

In the present investigation data indicated that, the lowest TCB of wastewater irrigation canals was detected in Giza (6.2 log cfu/ml), while the highest values were detected in Qalubia $(8.4 \mathrm{cfu} / \mathrm{ml})$. These values are higher than those obtained by Gedamy et al., (2012) in El Saff area Giza, where TCB ranged from $\left(2 \times 10^{4}\right.$ to $\left.276 \times 10^{4} \mathrm{cfu} / \mathrm{ml}\right)$ and $\left(4 \times 10^{4}\right.$ to $\left.36.0 \times 10^{5} \mathrm{cfu} / \mathrm{ml}\right)$ at $22^{\circ} \mathrm{C}$ and $37^{\circ} \mathrm{C}$, respectively; and also, higher than those reported by Cui et al., (2019) in which TCB bacteria ranged from $\left(3.6 \times 10^{6}\right.$ to $\left.4.3 \times 10^{6} \mathrm{cfu} / \mathrm{ml}\right)$ for wastewater. Similar results obtained by Hassan et al., (2018), where TCB ranged from $\left(158 \times 10^{5}\right.$ to $\left.0.1 \times 10^{5} \mathrm{cfu} / \mathrm{ml}\right)$ in some irrigation canal in Egypt and agree with the results obtained by AL-Jaboobi et al., (2103) in yemen wastewater canal where the main value of heterotrophic counts (HPC) ranged from $\left(1.3 \times 10^{7}\right.$ to $\left.8.1 \times 10^{6} \mathrm{cfu} / \mathrm{ml}\right)$. Regarding to total coliforms, data revealed that the lowest values were detected in Giza as log count $5.7 \mathrm{cfu} / \mathrm{ml}$, while the highest values were detected in Qalubia as $\log$ count $7.0 \mathrm{cfu} / \mathrm{ml}$. These results are higher than those reported by Hassan et al., (2018), where the count of coliforms in irrigation water ranged from $\left(93 \times 10^{3}\right.$ to $\left.0.1 \times 10^{3} \mathrm{cfu} / \mathrm{ml}\right)$, and also higher than those reported by Akinde et al., (2016) which ranged from $\left(1.40 \times 10^{3}\right.$ to $\left.1.40 \times 10^{5} \mathrm{cfu} / \mathrm{ml}\right)$ with a mean of $\left(1.27 \times 10^{4} \mathrm{cfu} / \mathrm{ml}\right)$. On the other hand, similar results obtained by Cui and Liang (2019), where total coliform ranged from $\left(1.0 \times 10^{4}\right.$ to 6.0 $\times 10^{5} \mathrm{cfu} / \mathrm{ml}$ ) Regarding to staphylococci bacteria, data showed that the lowest values were detected in Giza as $\log$ count $4.3 \mathrm{cfu} / \mathrm{ml}$, while the highest values were detected in Kalubia as log count 7.1 $\mathrm{cfu} / \mathrm{ml}$. This result is higher than those reported by Weldezgina et al., (2016), this high count of 
staphylococci might be due to mixing with drainage water or from dumbing of wastes into water streams.

For vegetable samples, the mean TCB were 5.7, 6.6, and $6.3 \mathrm{log} \mathrm{cfu} / \mathrm{gm}$ for Cucumber in Giza, Qalubia and Sharkia, respectively. These result is higher than those obtained by Gambo et al., (2019) who found that TCB of Cucumber for the examined areas ranged from 5.8 to $8.4 \times 10^{4}$ and also higher than those reported by Gimba et al., (2015) which was $\left(3 \times 10^{4}\right)$. While, these results were lower than those obtained by Ibn yassin et al., (2007) and Ahmed et al (2019), which were (10 $\left.{ }^{8} \mathrm{cfu} / \mathrm{g}\right)$ and (4.56 to $8.09 \log \mathrm{cfu} / \mathrm{gm})$, respectively. On the other hand, similar results (5.9 log cfu/gm) obtained by Abaza et al., (2018). The mean counts of Lettuce in the present study were 6.2, 7.0 and $6.4 \log \mathrm{cfu} / \mathrm{gm}$ in Giza, Qalubia and Sharkia, respectively. These result agree with those reported by Kouassi et al., (2019) and Ahmed et al (2019) and lower than those obtained by Somda et al., (2019). On the other hand, these results much higher than those obtained by Sahile et al., (2018) which was $4.53 \mathrm{log}$ $\mathrm{cfu} / \mathrm{gm}$. In the present investigation, mean counts of TCB in Arugula were 6.3, 6.9 and $6.7 \mathrm{log} \mathrm{cfu} / \mathrm{gm}$ in Giza, Qalubia and Sharkia, respectively. These results is in line with these reported by Abaza et al., (2018) which was $7.7 \mathrm{log} \mathrm{cfu} / \mathrm{gm}$ and higher than those reported by Khalil and Gomaa et al., (2014) which was $5.5 \mathrm{log} \mathrm{cfu} / \mathrm{gm}$ and Faour-Klingbeil et al., (2016) as $3.9 \mathrm{log} \mathrm{cfu} / \mathrm{gm}$. Presence of aerobic organisms in the result reflects the exposure of the sample to any contamination and in general, the existence of favorable conditions for multiplication of microorganisms Abaidoo et al., (2006).

The more related finding to this study was a study conducted by Nguz et al., (2005) and Johnston et al ., (2012) reported the means of aerobic mesophilic count ranged from 4.5 to $6.2 \mathrm{log}$ cfu/gm on fresh produces Sahile et al ., (2018). In the current study the mean total coliforms count was 4.9, 5.0 and 5.2 for Cucumber; 5.1, 5.7 and 5.5 for Lettuce and 5.2, 5.6 and 5.6 for Arugula with mean of $5.3 \log \mathrm{cfu} / \mathrm{gm}$ for all vegetable samples. This is agree with that reported by Nguz et al. (2005), who showed that mixed vegetables was still found to harbor high levels of TC (5.9 log cfu/gm) and higher than reported by Faour-Klingbeil et al., (2016) as 4.15 $\pm 0.0 \log$ MPN/100 g. On the other hand, total coliforms count for Lettuce ranged from 3.36 to $6.87 \mathrm{log} \mathrm{cfu} / \mathrm{gm}$ and total coliform bacteria ranging from 2.75 to $6.45 \mathrm{log} \mathrm{cfu} / \mathrm{gm}$ for Cucumber. In study done by Ahmed et al (2019), which is line with current study. The overall mean count of staphylococci for vegetables was $4.77 \mathrm{log} \mathrm{cfu} / \mathrm{gm}$ this is higher than those reported by Weldezgina et al. (2016) in which the mean count of staphylococci for vegetable samples ranged from 2.55 to $2.97 \mathrm{log} \mathrm{cfu} / \mathrm{gm}$ and in line with Guchi et al., (2010), who reported 4.55 and $4.97 \log \mathrm{cfu} / \mathrm{gm}$. Increased staphylococci count in vegetables during study period and areas might be as a result of contaminated irrigation water or contact of vegetables with soil which accumulate pathogen from irrigation water according to and long term irrigation by wastewater or contaminated canals where there were a positive relation between staphylococci in wastewater irrigation canal and staphylococci.

\section{Detection, isolation and identification of the pathogenic bacterial strains from irrigation water, soil and vegetables irrigated with wastewater}

Pathogenic bacterial strains of wastewater irrigation, soil and vegetable irrigated with wastewater (Arugula, Lettuce and Cucumber), which collected from the three Egyptian Governorates (Giza, Sharkia and Qalubia) were determined and data summarized in Table (4). Results indicated that bacterial strains of different collected samples are variable among the three Governorates. In the water samples, data proved that $S$. aureus and E. coli $s p$. was the predominates in the three Governorates, which detected in all the samples collection of the three Governorates. On the other hand, Proteus sp. and Klebseilla sp. was detected in all collected samples of Qalubia, whereas, Proteus sp. was the predominates in Sharkia samples. Data showed that Salmonella $s p$. detected in $89 \%$ of the samples collection from Sharkia, 78\% of Qalubia and 67\% from Giza. Citrobacter sp., Pseudomonas and Provedincia were also detected in (56 to $78 \%),(44$ to $78 \%$ ) and (56 to $89 \%)$ of the samples collection from Qalubia, Sharkia and Giza, respectively.

With respect to the soil samples, data in the same table indicate that, Proteus sp., Citrobacter sp. and $S$. aureus was the predominates in the three Governorates, which detected in all the samples collection of the three Governorates. Whereas, E. coli sp. was detected in all samples collection of Qalubia. Salmonella sp., Klebseilla sp., Pseudomonas and Provedincia were also detected in (44\% to $89 \%),(33 \%$ to $89 \%)$ and (44\% to $78 \%$ ) of samples collection from Qalubia, Sharkia and Giza, respectively. 
Regarding to vegetable samples, data in Table (4) proved that, E. coli sp., Salmonella sp., Proteus sp., Klebseilla, Citrobacter sp., S. aureus, Pseudomonas sp. and Providencia was detected in different collected samples (Arugula, Cucumber and Lettuce) from the three Governorates. Data in Fig. (1) proved that the highest percentage of $S$. aureus was detected in Sharkia (67\%), followed by Qalubia (63\%) and Giza (59\%). Regarding to E. coli its detected in $48 \%, 41 \%$ and $30 \%$ of the collected samples from Giza, Qalubia and Sharkia, respectively. The corresponding values of Salmonella $s p$. were 26, 22 and 19\%, in this order. Data showed that proteus sp., klebseilla sp., citrobacter sp., pseudomonas and providencia sp. were also detected (Fig.1). Regarding to Fig. (2), data indicated that leafy vegetables (Arugula and Lettuce) were more contaminated by bacteria than fruit vegetables (Cucumbers). Data also proved that, Arugula and Lettuce are more contaminated by $S$. aureus followed by proteus $s p$., citrobacter $s p$. and $E$. coli $s p$.

Table 4: Prevalence and distribution percentage of the pathogenic isolates in water, soil and vegetables sample collected from Qalubia, Sharkia and Giza governorates

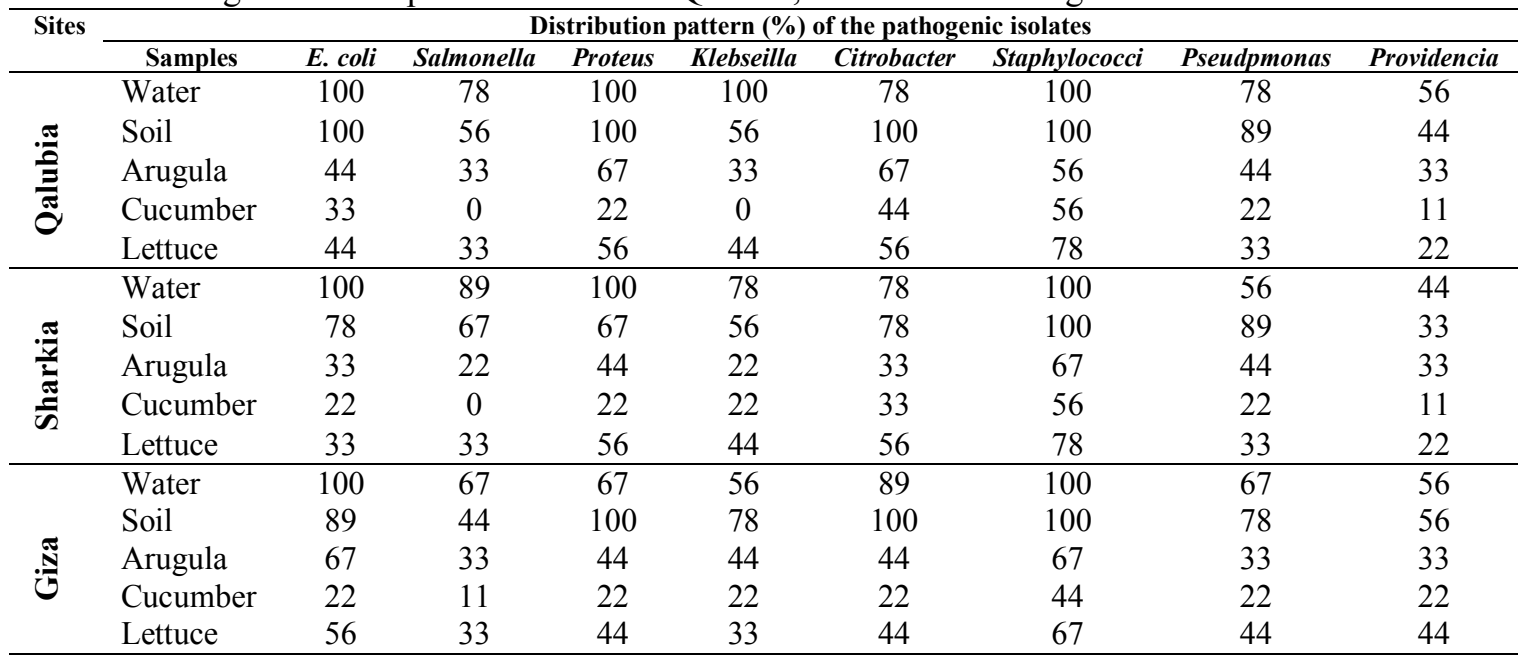

In our study enterobacteriacea is the most predominated group to which pathogens isolated have been belong. Similar findings reported by Nega and Sahile, (2018) which isolate five bacterial species from vegetable irrigated by contaminated streams, i.e. Escherichia coli, Klebsiella species, Proteus species, Enterobacter species, Pseudomonas species, which all belongs to enterobactereacea group. Water samples of the current study have pathogens in order of Staphylococci $(100 \%)=$ E. coli $(100 \%)>$ proteus $(89 \%)>$ Citrobacter $(81)>$ Klebsiella $(78 \%)=$ Salmoneela $(78)>$ Pseudomonas $(67 \%)>$ Provedincia $(52 \%)$. This in line with Gedamy et al., (2012) who found that E. coli is the main predominate species, the main indicator of faecal pollution, which causes gastro intestinal disorder as diarrhea, fever and vomiting. Also many bacterial strains isolated and identified from El saff water resources in Giza Egypt, the identified species are E.coli, Pseudomonas flourcsence, Klebsiella pneumonia, Salmonella cloerasuls, and Proteus vulgaris and very close with Shawer, (2016) who detect many bacterial strains in irrigation water canal in Egypt-Qalubia as Staphyllococci sp. (93\%), Pseudomonas sp. (88.7\%), E.coli (91.2\%) and Salmonella sp. (85\%). However, Osman et al., (2011), El bahnasawi, (2014) isolate Staphylococci and P. aeruginosa from water effluent in Egypt. Cui and Liang (2019) detected E. coli in wastewater before and after treatment. The presence of $P$. aeruginosa in water reflects that the canal water subjected to sewage, agricultural runoff, industrial effluents, and environmental disturbances (Hassanein et al., 2013). On the other hand, Rifaat, (2007) isolated Pseudomonas sp. from water samples from El-Gezera in River Nile at Cairo. While, Yehia and Sabae, (2011) isolated P. aeruginosa from El- Salam canal - Egypt. However, Elbahnasawy, (2013) isolated P. aeruginosa from Rosetta branch Nile- Egypt. Also, Akinde et al., (2016) isolated Klebsiella pneumonia, Pseudomonas aeruginosa, Escherichia coli, Enterobacter cloacae, Salmonella enteritidis, Shigella flexneri, Citrobacter diversus, Citrobacter freundii, Serratia marcescens and Salmonella typhi from contaminated water which used for irrigation. The order for isolate from vegetable samples are Staphylococci $(63 \%)>$ Citrobacter $(44)>$ Proteus $(42 \%)>$ E.coli 
$(40 \%)$, Pseudomonas $(33 \%)>$ Klebsiella $(30 \%)>$ Provedincia $(26 \%)>$ Salmonella $(22)$, which reflect the capability of pathogen colonize vegetables surfaces due variety of mechanisms to protect themselves from surrounding environmental conditions. As in our study Staphylococci is the most predominate gram positive bacteria in vegetables. Ehimemen et al., (2019) showed that Staphylococcus aureus was the most prevalent Gram-positive bacteria presented in vegetables. Similarly, E. coli, Klebsiella spp. and Citrobacter is the major Gram-negative bacterial strains found associated with the vegetables and that microbial contamination might be due to contact with soil, dust and water. Also, Akinde et al (2016) found that the most predominate bacteria from vegetables were Klebsiella pneumonia, Pseudomonas aeruginosa, Escherichia coli. From the above finding the need to find a cheap way in line with economic situation of our country to reduce or eliminate these pathogens either from vegetables or from the source of them.

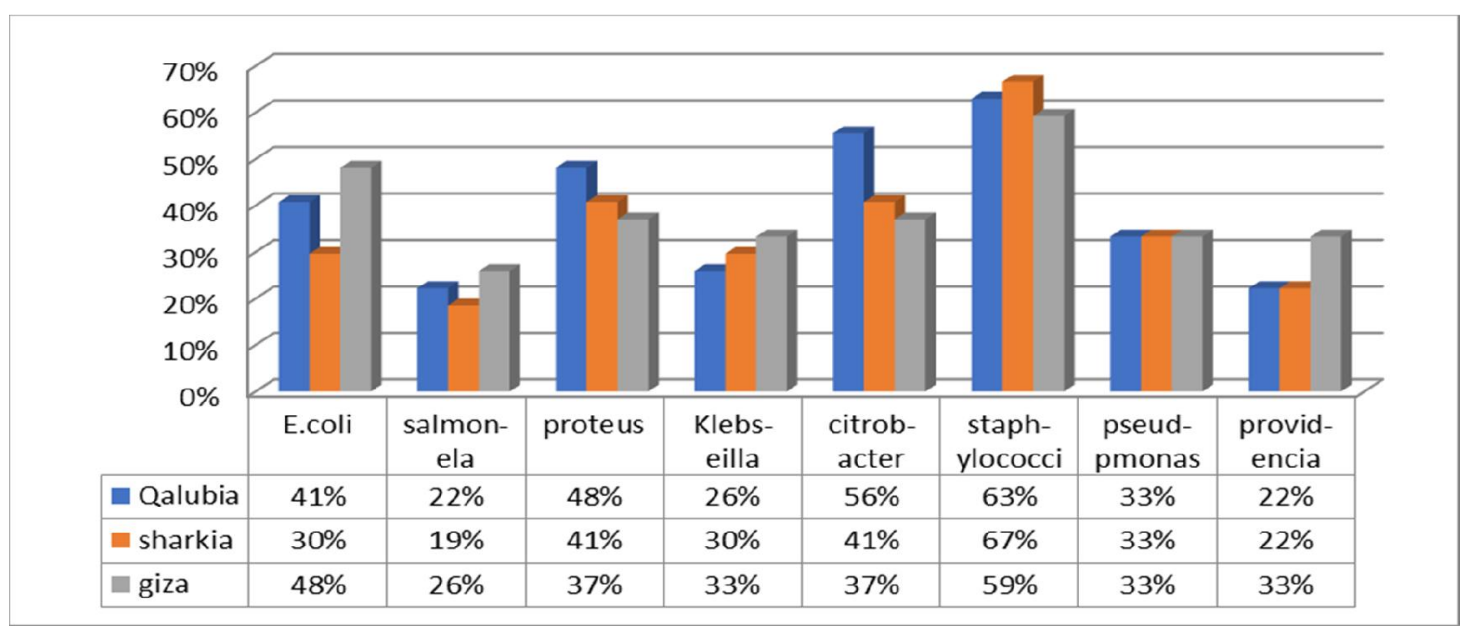

Fig. 1: Distribution of Pathogenic isolates in each governorate

\section{Percent of Pathogenic isolate in each vegetable type of the three} governorates

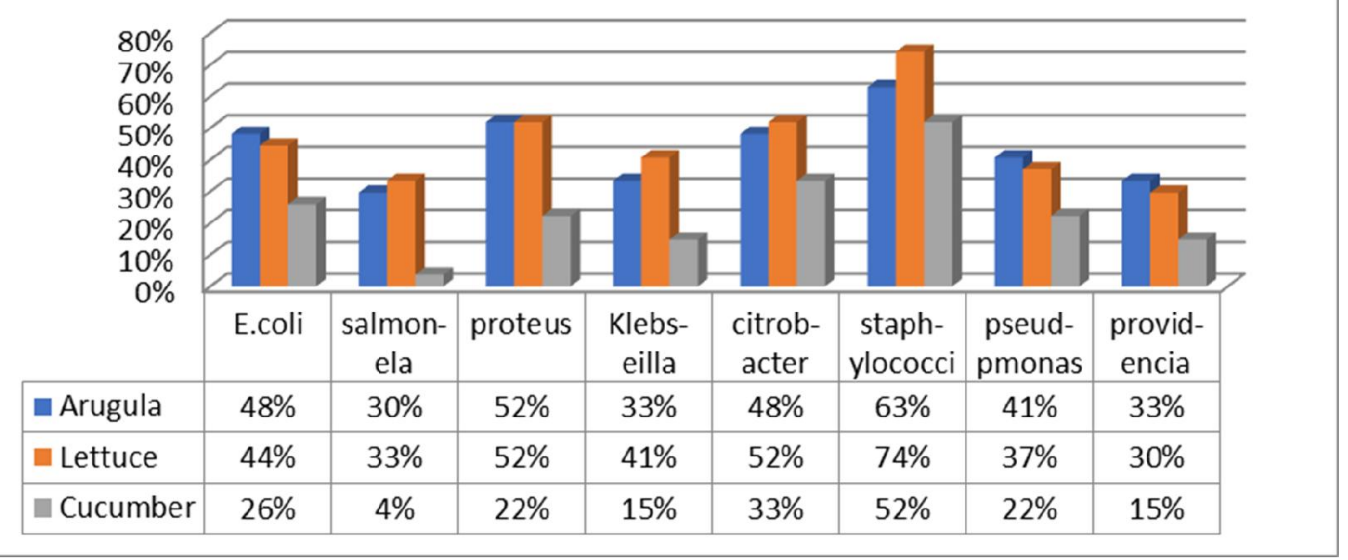

Fig. 2: Pathogenic isolate (\%) in each vegetable type of the three governorates

\section{Conclusion}

It could be concluded that wastewater irrigation canal which practiced to vegetable containing heavy load of bacteria, coliforms and staphylococci in addition to very harmful pathogenic bacteria that affect human health. When such water used for irrigation of agriculture soil and vegetables, bacteria accumulate into soil and transferee to plant by means of many mechanisms some attached to the surface while others penetrate plant skin through stomata or any wounds at the surface to protect themselves from surrounding environmental condition and so cause diseases to consumers especially 
when eaten raw. Also, we concluded that leafy vegetables retain many microbes than fruity one and this is might be due to large surface area. This study is a warning bill to stimulate concerned entities in Egypt for the necessarily treatment of wastewater before use and the government should make farmers aware of the dangers of irrigation with wastewater.

\section{References}

Abaza, A., 2017. Bacteriological assessment of some vegetables and ready-to-eat salads in Alexandria, Egypt. Journal of Egyptian Public Health Association, 92(3), 177-187.

Afolabi, O. R., and A. R. Oloyede, 2013. Irrigation water as possible source of food borne pathogens in raw vegetables. Journal of Natural Sciences Engineering and Technology, 9(2), 117-122

Ahmed, S., M. A. Siddique, M. Rahman, M. L. Bari, and S. Ferdousi, 2019. A study on the prevalence of heavy metals, pesticides, and microbial contaminants and antibiotics resistance pathogens in raw salad vegetables sold in Dhaka, Bangladesh. Heliyon, 5(2), e01205.

Akinde, S. B., A. A. Sunday,F. M. Adeyemi,I. B. Fakayode,O. O. Oluwajide, A. A. Adebunmi, and C. O. Adebooye, 2016. Microbes in Irrigation Water and Fresh Vegetables: Potential Pathogenic Bacteria Assessment and Implications for Food Safety. Applied Biosafety, 21(2), 89-97.

Alegbeleye, O. O., I. Singleton, and A. S. Sant'Ana, 2018. Sources and contamination routes of microbial pathogens to fresh produce during field cultivation: a review. Food Microbiology, 73, 177-208

Alemu, G., M. Mama, and M. Siraj, 2018. Bacterial contamination of vegetables sold in Arba Minch Town, Southern Ethiopia. BMC Research Notes, 11(1), 775.

Al-Jaboobi, M., M. Bouksaim,M. Tijane,and S. El-Ariqi, 2013. Agricultural quality evaluation of wastewater, used in Yemen vegetables production. Middle East Journal of Scientific Research, 16(5), 667-677.

American Public Health Association (APHA), 1995. Standard methods for the analysis of water and waste water. In: $19^{\text {th }}$ ed. Washington, DC: American Public Health Association (APHA).

Aruscavage, D., S.A. Miller, I.M.L. Lewis, K.E.N. Lee, and J.T. LeJeune, 2008. Survival and dissemination of Escherichia coli $\mathrm{O} 157: \mathrm{H} 7$ on physically and biologically damaged lettuce plants. Journal of Food Protection 71(12), 2384-2388

Assessing and Mitigating Risk in Low-Income Countries; IWMI: Colombo, SriLanka, 2010; pp. 101126.

Awe, S., F. Gimba,S.N. Madueke, 2015. Bacteriological and parasitological assessment of fresh vegetables and fruits sold in two major markets in Lokoja, Kogi State Nigeria. Am J Nutr Food Sci., 1(2):32-37

Badawy, R. K., A. A. El-Gawad,and H. E. Osman, 2013. Health risks assessment of heavy metals and microbial contamination in water, soil and agricultural foodstuff from wastewater irrigation at Sahl El-Hessania area, Egypt. J. Appl. Sci. Res., 4, 3091-3107.

Beuchat, L. R., 2002. Ecological factors influencing survival and growth of human pathogens on raw fruits and vegetables. Microbes and Infection, 4(4), 413-423

CAPMAS (Central Agency for Public Mobilization and Statistics), 2016. Statistical yearbook. Cairo. Ref. No. 71-01111-2016. http://www.capmas.gov.eg. Accessed 21 Mar 2017

Cui, B., and S. Liang, 2019. Monitoring Opportunistic Pathogens in Domestic Wastewater from a Pilot-Scale Anaerobic Biofilm Reactor to Reuse in Agricultural Irrigation. Water, 11(6), 1283.

Debnath, M., V. Chejara, B. K. Vijaya,D. S. Bika, S. Kumar, A. Dixit,... and V. Jain, 2014. Evaluation of quality and impact of untreated wastewater for irrigation. Am. J. Res. Commun., 2, 1-43.

Ehimemen, N. H., M. F. Mukhtar,and N. Salisu, 2019. Prevalence of Bacterial Loads on some Fruits and Vegetables Sold in Kaduna Central Market, Northwestern Nigeria. Journal of Applied Sciences, 19(1): 20-24.

El-Bahnasawy, M.A.H., 2013. Assessment of Gamma Irradiation on Antibiotic Resistant Bacteria Isolated from River Nile and Drainage Water in Egypt. Master Thesis, Botany and Microbiology Dept. Fac. Sci., Al-Azhar University., Egypt. 
Elbeih, S.F. and A.M. El-Zeiny, 2018. Qualitative assessment of groundwater quality based on land use spectral retrieved indices: Case study Sohag Governorate, Egypt. Remote Sens. Appl., Soc. Environ., 10: 82- 92.

El-Gamal, T.T. and M.H. Housian, 2016. Wastewater Challenges and the Successful Implementation of Constructed Wetlands in Egypt (Egypt), case 3. Cited from: Hiroshan Hettiarachchi and Reza Ardakanian (eds). (2016). Safe Use of Wastewater inAgriculture: Good Practice Examples. United Nations University, Institute for Integrated Management of Material Fluxes and of Resources (UNU-FLORES)

Eraky, M.A., S.M. Rashed, M.E. Nasr, A.M.S. El-Hamshary, and A.S. El-Ghannam, 2014. Parasitic contamination of commonly consumed fresh leafy vegetables in Benha, Egypt. J Parasitol Res 2014:1-7.

Faour-Klingbeil, D., E. C. Todd,and V. Kuri, 2016. Microbiological quality of ready-to-eat fresh vegetables and their link to food safety environment and handling practices in restaurants. LWT, 74, 224-233.

Farhadkhani, M., M. Nikaeen,G. Yadegarfar,M. Hatamzadeh,H. Pourmohammadbagher,Z. Sahbaei,and H. R. Rahmani, 2018. Effects of irrigation with secondary treated wastewater on physicochemical and microbial properties of soil and produce safety in a semi-arid area. Water Research, 144, 356-364.

Food and Agricultural Organization of the United Nations, World Health Organization. The Use of Microbiological Risk Assessment Outputs to Develop Practical Risk Management Strategies: Metric to Improve Food Safety. Rome, Italy: Food and Agricultural Organization of the United Nations; 1996.

Food and Drug Administration. Bacterio-logical analytical manual online. January2001 [cited 2005 Feb 10]. Available fromhttp://www.cfsan.fda.gov/ ebam/bam-mm.html

Gedamy, Y., A. El-Aassar,and A. Abdel-Gawad, 2012. Pollutants detection in water resources at El Saff Area and their impact on human health, Giza Governorate, Egypt. Int J Environ, 1(1), 114.

Gomes, C., P. Da Silva,R.G. Moreira,E. Castell-Perez,E.A. Ellis, and M. Pendleton, 2009. Understanding $E$. coli internalization in lettuce leaves for optimization of irradiation treatment. International Journal of Food Microbiology, 135(3), 238-247.

Guchi, B., \& Ashenafi, M. (2010). Microbial load, prevalence and antibiograms of salmonella and Shigella in lettuce and green peppers. Ethiopian Journal of Health Sciences, 20(1): 41-48.

Hassan, E. A. E., and N. A. Abdalla, 2018. Bacteriological and Physicochemical Screening of Some Irrigation Canals at Nile Delta, Egypt. The Egyptian Journal of Experimental Biology (Botany).

Hassanein, A.M.; K.A. Abdel Rahim, Y.M. Sabry, I. Mohamed, and H.A. Abd El Azeiz, 2013. Physicochemical and microbiological studies of River Nile water in Sohag governorate. Journal of Environmental Studies, 10: 47-61.

Huibers, F.P., O. Moscoso, A. Durán, J.B. van Lier, 2007. Use of wastewater in agriculture: The water chain

Ibenyassine, K., R. A. Mhand,Y. Karamoko,B. Anajjar,M. Chouibani,and M. M. Ennaji, 2007. Bacterial pathogens recovered from vegetables irrigated by wastewater in Morocco. Journal of Environmental Health, 69(10), 47-51.

Islam, M., M.P. Doyle,S.C. Phatak,P. Millner, and X. Jiang, 2004. Persistence of enterohemorrhagic Escherichia coli $\mathrm{O} 157: \mathrm{H} 7$ in soil and on leaf lettuce and parsley grown in fields treated with contaminated manure composts or irrigation water. Journal of Food Protection 67(7), 13651370.

James.Y., J.B. Gambo, and A.M. Aliyu, 2019. Microbiological Assessment of Some Vegetables Obtained from Irrigated farms within Kaduna Metropolis. IOSR Journal of Pharmacy and Biological Sciences, 14(3), 26-30

Johannessen, G. S., S. Loncarevic and H. Kruse, 2002. Bacteriological analysis of fresh produce in Norway. International Journal of Food Microbiology, 77(3), 199-204.

Kayombo, M. C., and A. W. Mayo, 2018. Assessment of Microbial Quality of Vegetables Irrigated with Polluted Waters in Dar es Salaam City, Tanzania. Environment and Ecology Research, $6(4), 229-239$ 
Khalid, S., M. Shahid,I. Bibi,T. Sarwar,A. H. Shah,and N. K. Niazi, 2018. A review of environmental contamination and health risk assessment of wastewater use for crop irrigation with a focus on low and high-income countries. International Journal of Environmental Research and Public Health, 15(5), 895.

Khalil, R., and M. Gomaa, 2014. Evaluation of the microbiological quality of conventional and organic leafy greens at the time of purchase from retail markets in Alexandria, Egypt. Pol $\mathrm{J}$ Microbiol, 63, 237-243.

Kouassi, C. K., A. K. Kouassi,M. K. Yao,G. A. Kouassi,and R. Koffi-Nevry, 2019. Assessment of the Risk of Microbial Contamination of an Urban Crop in the City of Daloa (Côte d'Ivoire): Case of Lettuce (Lactuca sativa L.). Journal of Food Research, 8(3), 122-132.

Maffei D.F., V.O. Alvarenga, A.S. Sant'Ana, B.D.G.M. Franco, 2016. Assessing the effect of washing practices employed in Brazilian processing plants on the quality of ready-to-eat vegetables. Food Sci Technol LEB 69:474-481

Markhous, N. A., A. Tidjani,A. A. Doutoum,B. Nadlaou,D. M. Doungous and B. Abdourahamane, 2019. Microbiological Characteristics and Resistance Profile of Isolated Bacteria in Market Garden Products in N'Djamena, Chad. Journal of Food Stability, 2(1), 21-30.

Mcheik, A., A. Awad,A. Fadel,C. Mounzer and S. Nasreddine, 2018. Effect of Irrigation Water Quality on the Microbial Contamination of Fresh Vegetables in the Bekaa Valley, Lebanon. American Journal of Agriculture and Forestry, 6(6), 191-197.

Mritunjay, S. K., and V. Kumar, 2017. A study on prevalence of microbial contamination on the surface of raw salad vegetables. 3 Biotech, 7(1), 13.

Nega, R and S. Sahile, 2018. The Effect of Irrigation Water the Microbial Quality and Safety of Vegetables: The Case of "Bisnet" River at Gondar Town. Int. J. Biopro. Biotechnol. Advance, 4(1): 127-143.

Nguz, K., J. Shindano, S. Samapundo, and A. Huyghebaert, 2005.Microbiological evaluation of fresh-cut organic vegetables produced in Zambia. Food Control, 16(7): 623-628.

Obeng, F. A., P. B. Gyasi, M. Olu-Taiwo and F. P. Ayeh-kumi, 2018. Microbial Assessment of Tomatoes (Lycopersicon esculentum) Sold at Some Central Markets in Ghana. BioMed Research International, 1-7

Obi, C.L., N. Potgieter, P.O. Bessong, and G. Matsaung, 2002. Assessment of the microbial quality of river water sources in rural Venda communities in South Africa. Water SA, 28(3): 287-292.

Osman, G.A.; M.M. Kamel, H.M. Hassan, and A.Z. Al-Herrawy, 2011. Microbial Quality of Nile Water and Drinking Water in Some Areas of Greater Cairo, Egypt.

Platform, S. A. I., 2010. Water conservation technical briefs. TB7-Wastewater use in agriculture. Sustainable Agriculture Initiative (SAI). Brussels, Belgium

Qadir, M., D. Wichelns, L. Raschid-Sally, P.G. McCornick, P. Drechsel, A. Bahri and P.S. Minhas, 2010. The challenges of wastewater irrigation in developing countries. Agricultural Water Management, 97(4): 561-568.

Rai, P. K., and B. D. Tripathi, 2007. Microbial contamination in vegetables due to irrigation with partially treated municipal wastewater in a tropical city. International Journal of Environmental Health Research, 17(5), 389-395.

Scott, C.A., N.I. Faruqui, L. Raschid-Sally, 2010. Wastewater Use in Irrigated Agriculture: Management. CAB Internationalin association with theInternational Water Management Institute and the International Development Research Centre. ISBN 0851998232 (CABI hardback edition.

Shawer, E. El., 2016. Evaluation of microbial pollution of El-Sharqawya Canal-River Nile- Egypt. Master Thesis, Botany and Microbiology Dept. Fac. Sci., Al-Azhar University., Egypt.

Somda, M. K., S. Samake,D. Kabore,M. Nikiema,I. Mogmenga, Y. Dabire and A. S. Traore, 2019. Assessment of Heavy Metals and Microbial Pollution of Lettuce (Lactuca sativa) Cultivated in Two Sites (Paspanga and Tanghin) of Ouagadougou, Burkina Faso. Journal of Environmental Protection, 10(3): 454-471.

Steele, M. and J. Odumeru, 2004. Irrigation water as source of foodborne pathogens on fruit and vegetables. Journal of Food Protection 67(12), 2839-2849. 
Tamer A., B. Noura, G. Biju and E. Maha, 2017. Assessment of Marginal Quality Water for Sustainable Irrigation Management: Case Study of Bahr El-Baqar Area, Egypt. Water Air, \& Soil Pollution, 228(6), 214 DOI 10.1007/s11270-017-3397-2.

Thebo, A.L., P. Drechsel, E.F. Lambin, and K.L. Nelson, 2017. A global, spatially-explicit assessment of irrigated croplands influenced by urban wastewater flows. Environmental Research Letters, 12(7), 074008.

Weldezgina, D. and D. Muleta, 2016. Bacteriological Contaminants of Some Fresh Vegetables Irrigated with Awetu River in Jimma Town, Southwestern Ethiopia. Advances in Biology Advances in Biology, 1-11.

WHO, 2006. Guidelines for the Safe Use of Wastewater, Excreta and Greywater: Volume II Wastewater Use in Agriculture. World Health Organization, Geneva, Switzerland

World Health Organization, 2003. Promoting fruit and vegetable consumption around the world. Global Strategy on Diet, Physical Activity and Health; World Health Organization: Geneva, Switzerland.

Yehia, H.M. and S.Z. Sabae, 2011. Microbial pollution of water in El-Salam canal, Egypt. Amer. Eura. J. Agric. and Environ. Sci., 11 (2):305-309 